\title{
CAPITALIZATION OF SECONDARY WINE PRODUCTS - AN OPPORTUNITY FOR THE WINE SECTOR OF REPUBLIC OF MOLDOVA AND ROMANIA
}

\author{
Grigore Musteață ${ }^{1}$, Anatol Balanuță ${ }^{1}$, ORCID ID: 0000-0002-4153-1065, \\ Vladislav Reșitca ${ }^{1 *}$, ORCID ID: 0000-0002-6063-1731, \\ Razvan Vasile Filimon 2, Marius Mihai Băetu 2, ORCID ID: 0000-0001-5343-5401, \\ Antoanela Patraş², ORCID ID: 0000-0002-4054-4884 \\ ${ }^{1}$ Technical University of Moldova, str. Studenţilor, 9/9, Chisinau, Republic of Moldova, \\ 2"Ion Ionescu de la Brad" University of Agricultural Sciences and Veterinary Medicine of Iaşi, Romania \\ *Corresponding author: Vladislav Reșitca, vladislav.resitca@ftmia.utm.md
}

\begin{abstract}
One of the economy key sectors of Republic of Moldova and Romania is the wine sector, where a progressive trend has prevailed in recent years. But to increase its efficiency it is necessary to use the raw material in a complex way, producing both famous wines and other necessary products, as well as to comply with the rigors of ecological standards. The issue of wine by-products draws the attention and interest of researchers, regulators, industry and consumers and has urged the European Community to a zero waste economy by 2025. The article deals with the chemical composition of the main parts of grapes which depend on a number of factors, such as variety, climatic conditions of the year, vine and wine making practices, condition of the grapes, their maturity, etc. There have been presented physico-chemical characteristics of the wastes obtained from the grapes processing such as: bunches, grape pomaces, piquette and diffusion juice, seeds, wine yeast, tirighia and vinasse. Thus, by making use of wine wastes, a number of valuable products can be obtained that can be used for different purposes.
\end{abstract}

Keywords: Wine industry, grapes, grape pomaces, wine yeasts, grape seeds, vinasse.

Rezumat. Unul dintre sectoarele cheie ale economiei Republicii Moldova și României este ramura vitivinicolă, unde o tendință progresivă a predominat în ultimii ani. Însă pentru sporirea eficienței sale este necesar de a folosi materia primă într-un mod complex, obținând de rând cu faimoasele vinuri și alte produse necesare, precum și a se conforma rigorilor standardelor ecologice. Problema produselor vinicole secundare atrage atenția și interesul cercetătorilor, organismelor de reglementare, a industriei și consumatorilor și a îndemnat Comunitatea Europeană spre o economie zero deșeuri către anul 2025. În articolul dat este prezentată compoziția chimică a principalelor părți ale strugurilor care depind de un șir de factori, cum ar fi soiul, condițiile climaterice ale anului, practicele viticole și cele oenologice, starea de sănătate a strugurilor, gradul de maturitate a lor, etc. De asemenea, sunt prezentate caracteristicile fizico-chimice ale deșeurilor obținute la 
prelucrarea strugurilor cum ar fi: ciorchinii, tescovinele, pichetul și zeama de difuzie, semințele, drojdia de vin, tirighia și vinasa. Astfel, valorificând deșeurile de vin, se poate obține o serie de produse valoroase care pot fi utilizate în diferite scopuri.

Cuvinte cheie: Industria vinicola, struguri, tescovina, drojdii de vin, semințe de struguri, vinasa.

\section{Introduction}

The wine sector of Republic of Moldova and Romania has experienced a special development in the last 30 years, becoming one of the important sectors of the economy. But to increase its efficiency it is necessary to use the raw material in a complex way, obtaining along with the famous wines and other necessary products, as well as to comply with the rigors of ecological standards in order to prevent environmental pollution. The problem of agri-food industrial by-products and waste generation has attracted the interest of researchers, regulatory bodies, industry and consumers and urged the EU towards a zerowaste economy by 2025 [1]. Residues and side-off products, as pomace, seeds, stems, yeast and bacteria lees, organic acids (tartrate), $\mathrm{CO}_{2}$, water and other by-products of grape processing are currently an environmental problem, their recovery and reintroduction into the food technology circuit is one of the main objectives of sustainable horticulture. Unfortunately, only a few quantities of these materials are used for fertilization (exclusively in vineyards), animal feed, biomass for energetic purposes or generation of other products [2]. Although potential utility of this waste for value-added products is promising most of the wine side-off products are still underexploited [3]. Moreover, the food industry is facing the challenge of developing new foods with increased health benefits and meeting consumer's appreciation, some by-products of the wine sector showing high potential to be used in this purpose [4]. These imperatives are particularly important at the moment and emerge from the morphological composition of the grapes. It is as follows:

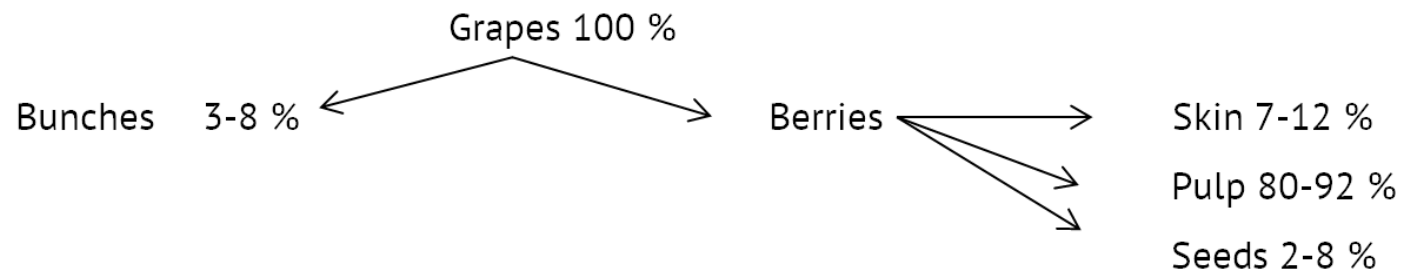

Globally, grapes are mostly used in two directions: fresh and dehydrated (raisins) especially in Turkey, Iran, Iraq, the Middle East, the USA, some African countries; and the second direction for industrial processing in order to obtain wine products, as natural wine or special wines (sparkling, aromatized, liqueur, etc.). The latter are obtained only from the liquid component of grapes, must, which is contained in the pulp and mesocarp. The other components result during the processing of the grapes as waste or by-products. They contain a number of valuable substances, which can be extracted by certain technologies, helping to streamline the industry.

\section{Classification of wine waste}

The amount of waste can reach up to $20 \%$ of the mass of processed grapes in some years. In Republic of Moldova and Romania, according to the Law on Vine and Wine, wine by-products present the waste from the processing of grapes and the manufacture of wine products [5]. These are attributed to:

1. Must bunches; 
2. Grape pomaces (sweet, fermented, alcoholic);

3. Piquette;

4. Diffusion juice;

5. Wine yeast;

6. Tirighia (wine stone);

7. Vinasse;

8. Marc.

In accordance with Republic of Moldova Government Decision no. 356 of 11.05 .09 for the approval of the Technical Regulation "The system of organization of the wine market and the traceability of products" the by-products obtained from waste are:

1. Alcohol from grape pomace;

2. Alcohol from wine yeast;

3. Tartaric products;

4. Enocolorant;

5. Grape seed oil;

6. Enotanins;

7. Feed;

8. Composts.

Here can be added biological gas, $\mathrm{CO}_{2}$, vinegar.

The quantity and quality of wine by-products depend on the chemical composition of the grapes, which can be schematically shown in the following figure:
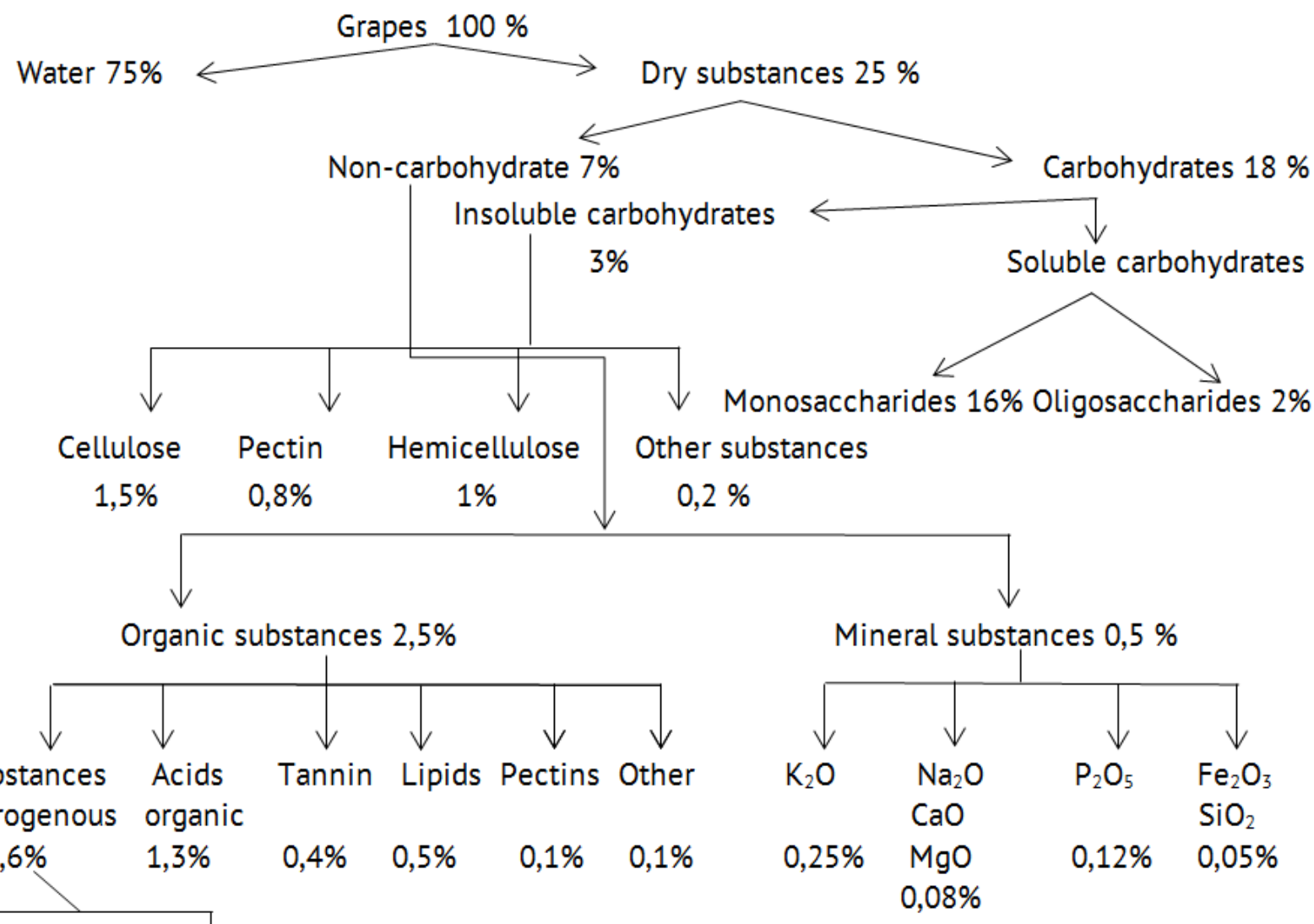

Proteins Non-protein substances

$0,2 \% \quad 0,4 \%$

Figure 1. Schematic diagram of the chemical composition of grapes [6]. 
The chemical composition of the main parts of the grapes depends on a number of factors, such as the variety, the climatic conditions of the year, the viticultural and oenological practices, the health of the grapes, their degree of maturation etc [7].

Table 1 shows the chemical composition of the main parts of the grapes, the values being expressed in \% by weight of the fresh grapes.

Table 1

Chemical composition of the main parts of grapes [8]

\begin{tabular}{lccccc}
\hline \multirow{N}{N}{$/ \mathrm{r}$} & The composition & \multicolumn{4}{c}{ The component parts of grapes } \\
\cline { 3 - 6 } & \multicolumn{1}{c}{ Water } & Rachis & Skin & Seeds & Pulp \\
\hline 1 & $78-80$ & $75-80$ & $25-45$ & $80-85$ \\
2 & Carbohydrates: & & & & \\
& - Glucose & - & - & - & $7,0-12,5$ \\
& - Fructose & - & - & - & $8,0-13,0$ \\
& - Sucrose & - & - & - & $0,1-0,15$ \\
& - Pentozan & $0,5-1,5$ & $0,5-1,0$ & $4,0-5,0$ & -
\end{tabular}

3 Organic acids:

- Tartaric acid

$\begin{array}{cccc}0,5-1,5 & 0,2-0,5 & - & 0,3-0,8 \\ 0,1-0,5 & 0,01-0,02 & - & 0,05-0,4 \\ - & - & - & 0,02-0,09 \\ - & - & - & 0,01-0,02\end{array}$

4 Polyphenols:

- Tannins

- Anthocyanins

$\begin{array}{cccc}3-5 & 0,5-1,0 & 5,0-8,0 & 0,01-0,02 \\ - & 0,2 & - & \text { Tinctorial } \\ & & & \text { varieties }\end{array}$

5 Nitrogenous substances:

- Amino acids

$\begin{array}{cc}- & 0,02-0,10 \\ 1,0-1,2 & 0,20-0,30 \\ 0,5-0,8 & 0,05-0,10 \\ - & -\end{array}$

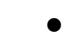

0,5-1,0

- Peptides, polypeptides

- Proteins

- Biogenic amines

$$
\begin{array}{cc}
0,5-2,0 & 0,01-0,20 \\
0,2-0,5 & 0,01-0,10 \\
- & 0,02
\end{array}
$$

6 Lipids:

- Fatty acids

- Phytosterols

$$
\begin{array}{cc}
0,01-0,02 & 0,08-0,20 \\
- & 0,01-0,04 \\
- & 0,01-0,05 \\
- & - \\
- & 0,02-0,10
\end{array}
$$

$9,0-18,0$

0,01-0,05

7 Pectic matter:

- Protopectin

- Pectin

- Gums

8 Primary flavors:

- Terpenes

\begin{tabular}{|c|c|c|c|}
\hline- & $0,01-0,10$ & Traces & - \\
\hline- & $0,10-0,50$ & Traces & - \\
\hline $2,0-3,0$ & $0,5-1,0$ & $2,0-4,0$ & $0,2-0,3$ \\
\hline $5,0-10,0$ & $3,0-4,0$ & $0,1-0,2$ & $2,0-4,0$ \\
\hline- & - & - & $0,01-0,08$ \\
\hline- & Pectolase & - & Oxidoreductases \\
\hline
\end{tabular}

- Terpene glycosides

9 Mineral substances

- $\quad 0,01-0,04$

$-$

$0,5-0,2$

$0,01-0,50$

10 Polysaccharide

- Cellulose 
As can be seen from the table, the chemical composition is very varied, the substances being unevenly distributed in all the component parts of the grapes.

\section{Waste characteristics}

The rachis represent $3-8 \%$ from the weight of the grapes and form their skeleton. The weight of the bunches depends on the variety, the degree of ripeness of the grapes, their state of health and the local ecopedoclimatic conditions. Most wine grape varieties have lignified bunches, they become stiff and crush easily during transport. If the peduncle is woody, it becomes short and thick and makes it difficult to harvest the grapes, especially in the case of mechanized, increasing losses. If the peduncle remains semi-lignified or even herbaceous, the grapes are easily harvested, but when they are pressed, must from bunches are obtained, which by its chemical composition reduces the quality of the must for wine: reduces its osmotic pressure and can give the wine the scent of bunches.

Analyzing the chemical composition of the bunches (from table 1), we can conclude that their capitalization is not convenient. As a rule, the bunches are not used unless they are used as compost.

Pomaces are dense residues obtained after separating the grape must (sweet pomace) or separating the wine (fermented pomace). Pomaces consist of skin, seeds, pulp, must or wine residues and possibly stalks [9]. Alcoholic pomace is also very rare, in the case of the production of red (Pastoral type) or white dessert wines (liqueur wines of Muscat varieties, in particular), because the technology of their production involves the alcoholization of the must. The most abundant in grape pomace are dietary fibers that are present in high levels (up to $85 \%$ depending upon the grape variety) and polyphenolic compounds that mainly (about 70\%) remain in pomace after the winemaking process [10]. Phenolic substances are concentrated in the grape skin and seeds, precisely that part which remains as pomace after grape processing [11]. The polyphenol content and composition of grape pomace vary with grape variety, climate condition, soil type, maturity and length of maceration [12].

According to their composition, pomaces differ greatly depending on the vinification method ("white", "red" or special wines method), as well as the techniques used in vinification. A common index of pomace regardless of the method of vinification is their humidity, which makes up 50 - 55\% (in pneumatic presses). The composition of the pomace in terms of the vinification method is shown in table 2.

Table 2

Composition of pomaces depending on the method of grape processing [6]

\begin{tabular}{llccc}
\hline \multirow{2}{*}{$\mathrm{N} / \mathrm{r}$} & \multirow{2}{*}{ Substance } & \multicolumn{3}{c}{ Method of wine making and obtaining pomace } \\
\cline { 3 - 5 } & & " in white" & ,in red" & alcoholic \\
\hline 1 & Carbohydrates (mono-, oligo-) & $5-10$ & - & $4-6$ \\
2 & Ethyl alcohol & - & $4-5$ & $4-8$ \\
3 & Tartrates (in tartaric acid) & $0,5-2,0$ & $0,7-2,5$ & $1,2-3,0$ \\
4 & Seeds & & $15-35$ & \\
& Oil,\% by mass & & $10-18$ & \\
\hline
\end{tabular}

The content of the substances that can be capitalized from pomaces is quite varied and indicatively oscillates as can be seen from the data in the table. Thus, it results that, in consequence of the capitalization of pomace by industrial means, can be obtained such products as ethyl alcohol, tartaric materials, grape oil, fodder, composts and biogas. 
The degree of extraction of pomaces varies between 70 and $80 \%$ (except for the extraction method by ion exchange), which leads to dilute solutions, which require increased energy consumption and reduce the economic efficiency of the processes [13]. In order to fit in rational terms, large quantities of raw materials are needed (special enterprises such as Ravenna, Italy or Focșani, Romania). Also, naturally dried pomace do not require expensive storage conditions, maintaining its biologically active properties [14].

Piquette and diffusion juice. The difference between these two wine wastes consists in the diffusion method. The piquette is obtained by static diffusion of the pomace in certain solvents. The diffusion juice is obtained as a result of the extraction of the soluble components of the pomace at special installations in dynamic regime (extractors), usually in several steps (3 - 6).

The basis for obtaining this waste is the diffusion process, which is expressed by the Fick-Einstein law:

Where:

$$
d C=\frac{R T}{N} * \frac{1}{6 \pi \eta r} * S \frac{d C}{d X} * d \tau
$$

$d C \quad$ - amount of substance that diffuses in a unit of time, $\mathrm{g}$;

$D \quad$ - diffusion coefficient

$$
D=\frac{R T 1}{N 6 \eta \eta r}
$$

$S$ - the surface through which it diffuses the compounds (sugars, tartrates), $\mathrm{cm}^{2} ; d C /$ $d X$ - the concentration gradient, $\mathrm{g} / \mathrm{cm}^{3}$, which constitutes the decrease of the concentration;

$d T$ - unit of time, sec, min; $R$ - gases constancy; $T$ - temperature, $\mathrm{K} ; N$ - Avogadro number; $\boldsymbol{X}$ - pi number; $\mathbf{X}$ - environmental viscosity, $\mathrm{Pa} \cdot \mathrm{sec} ; \boldsymbol{r}$ - radius of the particles from which the diffusion takes place, $\mathrm{cm}$.

This law reflects quite completely the direction of sugars extraction and tartaric compounds from pomaces. The dominant factor that will ensure the diffusion process is the diffusion coefficient, which largely depends on the temperature.

The diffusion juice is obtained by washing the pomace in multi-stage extractors. The degree of extraction of substances (sugars and tartrates) is illustrated in Table 4.

Table 3

Quantity of substance extracted when using the extractor with the countercurrent principle in 6 steps (\%) compared to the initial content [15]

\begin{tabular}{cccccccc}
\hline$a$ & \multicolumn{9}{c}{ Number of washes } & & $\begin{array}{c}\text { Number of } \\
\text { extraction } \\
\text { volumes }\end{array}$ \\
\cline { 2 - 7 } & 1 & 2 & 3 & 4 & 5 & 6 & 1 \\
\hline 1 & 50,00 & 66,67 & 75,00 & 80,00 & 83,55 & 85,71 & 2 \\
3 & 66,67 & 85,71 & 93,93 & 96,77 & 98,42 & 99,21 & 3 \\
\hline
\end{tabular}

a - the ratio of the liquid drained from the pomace to the soaked liquid.

The amount of substance extracted will be equal to:

$$
[1-1 /(1+a) n] * 100 \%
$$


The seeds are part of the pomace, but according to their value as by-products it is worth highlighting separately. The seeds make up 3-8\% of the berry weight, depending on the variety and climatic conditions of the year. The berries contain 1 - 4 seeds, generally 2 -3 (Keller, 2010).

The seeds are made up of two integuments, one external and one internal. The external one, as a rule, is lignified. It was found that there is a certain correlation between the number of seeds, weight and grain size, sugar content and acidity. Grains that have more seeds are larger, accumulate less sugar and more acids. The chemical composition of the seeds is shown in Table 1 . From the table we notice that the components that can be extracted are lipids and tannins, constituting respectively $9-18$ and 5 - 8\%.

The use of special separators allows the separation of the seeds, the yield of the process being depending on the humidity of the pomace and the content of the seeds in the initial pomace. Table 4 presents the results of research conducted within the scientificpractical institute of horticulture and food technologies [15].

Yield of seeds obtained from wet grape pomace

\begin{tabular}{ccccc}
\hline $\begin{array}{c}\mathrm{Nr} \\
\text { sample }\end{array}$ & $\begin{array}{c}\text { Moisture of the } \\
\text { pomace, } \%\end{array}$ & $\begin{array}{c}\text { Seeds content of } \\
\text { initial pomace, } \%\end{array}$ & $\begin{array}{c}\text { Seeds moisture, } \\
\%\end{array}$ & $\begin{array}{c}\text { Separation } \\
\text { efficiency, } \%\end{array}$ \\
\hline 1 & 62,3 & 28,7 & 42,3 & 67,6 \\
2 & 58,7 & 32,3 & 40,2 & 74,6 \\
3 & 55,4 & 32,4 & 39,8 & 70,9 \\
4 & 60,5 & 35,2 & 37,6 & 66,4 \\
5 & 56,8 & 38,8 & 41,3 & 78,3 \\
6 & 54,3 & 41,3 & 43,5 & 91,3 \\
7 & 53,6 & 45,6 & 45,2 & 89,5 \\
8 & 57,4 & 44,3 & 44,7 & 89,8 \\
\hline
\end{tabular}

We can conclude that the separation yield is higher if the humidity of the pomace is lower and the seed content in the pomace - higher.

Grape seed oil is rich in phenolic compounds, fatty acids, and vitamins, with economic importance to pharmaceutical, cosmetic, and food industry [16]. Grape seed contains $8 \%-20 \%$ of oil (dry basis) [17]. Considering that oil is the most valuable product obtained from grape seeds, in the same study was investigated the dependence of oil content in seeds, knowing that it depends on the variety, the degree of ripeness of the grapes and their place of origin. The results are presented in Table 5.

Table 5

Oil content of grape seeds of different varieties and wineries [15]

\begin{tabular}{cllcc}
\hline $\begin{array}{c}\text { No. } \\
\text { sample }\end{array}$ & $\begin{array}{c}\text { The grape } \\
\text { variety }\end{array}$ & $\begin{array}{c}\text { Grape growing } \\
\text { area }\end{array}$ & $\begin{array}{c}\text { Mass concentration of } \\
\text { sugars in grapes, g / } \\
\mathrm{dm}^{3}\end{array}$ & Seed oil content,\% \\
\hline 1 & Aligote & Bardar & 167 & 15,9 \\
2 & Feteasca & Bulboaca & 163 & 15,3 \\
3 & Rcațiteli & Cimișlia & 181 & 16,1 \\
4 & Sauvignon & Căușeni & 173 & 15,0 \\
\hline
\end{tabular}


Research on the fatty acid content of grapes has shown that in unrefined oil the main fatty acids are linoleic acid (74.06\% of the amount of triglycerides), oleic (15.17\%), palmitic (7.65\%) and stearic (2.63\%). The same 4 main acids in refined oil were 74.98 ; $15.96 ; 8.98$ and $2.83 \%$, respectively. So, after the fatty acid content, grape oil can be used as a cooking oil. This fact is also confirmed by the values of iodine, saponification and acid indices. In fact, in the south of France, where large areas are occupied by vines and large quantities of red grapes are vinified, grape seed oil is widely used in food, most often fresh for salads.

Wine yeast is the sediment obtained after the fermentation of the must and the separation of the solids. Wine lees are defined (EEC No. 337/79) as the residue that forms at the bottom of recipients containing wine, after fermentation, during storage or after authorized treatments, as well as the residue obtained following the filtration or centrifugation of this product [18]. Wine lees represent $2-6 \%$ of the total volume of wine produced and in addition to the yeast cells, the sediment contains salts of tartaric acid, polyglucides (pectins, gums, mucilages), phenolic compounds, proteins and interaction products, lipids, phosphates, sulfates [19].

According to the dry substance content, the yeast sediments are divided into 4 categories:

- Liquid yeasts, which contain up to $12 \%$ dry substance;

- Gravity sedimented yeasts with $12-30 \%$ dry substance;

- Pressed yeast, 30-60\% dry substance;

- Dry yeast.

At the same time, according to the type of wine, wine yeasts are dry yeasts and alcoholic yeasts.

Table 6 shows the characteristics of liquid yeasts [13].

Table 6

Characteristics of liquid yeasts

\begin{tabular}{lcc}
\hline \multicolumn{1}{c}{ The index } & \multicolumn{2}{c}{ The norm for liquid yeasts } \\
\cline { 2 - 3 } & Dry wines & Alcoholic wines \\
\hline Mass fraction of ethyl alcohol,\%, min & 6,0 & 10,0 \\
Mass concentration of sugars, recalculated in & - & 7 \\
invert sugar, g / $100 \mathrm{~cm} 3$, min. & 2,5 & 3,5 \\
Mass fraction of tartaric acid,\%, min. & $30-50$ & $30-50$ \\
Mass fraction of suspended substances,\% & & \\
Mass fraction of mineral substances insoluble & 1,0 & 1,0 \\
in hydrochloric acid,\%, max. & 0,15 & 0,15 \\
Mass fraction of iron, mg / dm3, max. & & \\
\hline
\end{tabular}

The table shows that in alcoholic yeasts the mass fraction of tartaric acid is higher than in dry yeasts, because they settle more easily under the action of ethyl alcohol. The content of different substances in $100 \mathrm{~kg}$ of pressed yeast is in medium (Table 7). 


\section{Content of substances in $100 \mathrm{~kg}$ of pressed yeast [20]}

\begin{tabular}{|c|c|c|}
\hline Name of the substances & Substances content & $\begin{array}{c}\text { The average value used for } \\
\text { the record }\end{array}$ \\
\hline Dry substance, kg & $40-70$ & 50 \\
\hline Potential anhydrous alcohol, & $4-14$ & 8 \\
\hline L & $4-6$ & 5 \\
\hline $\begin{array}{l}\text { - In dry wine sediments } \\
\text { - In the sediments of } \\
\text { alcoholic wines }\end{array}$ & $6-14$ & 10 \\
\hline $\begin{array}{l}\text { Tartaric compounds, } \\
\text { recalculated in tartaric acid, } \\
\mathrm{kg}\end{array}$ & $1-6$ & 3 \\
\hline Protein substances, kg & $13-30$ & 25 \\
\hline
\end{tabular}

Dry yeasts must correspond to the following requirements: humidity - max. $3 \%$; tartaric acid - at least 2.4\%; insoluble impurities - up to $50 \%$; the size of the pieces - $2 \mathrm{~cm}$.

Tirighia (wine stone) is the sediment that is deposited on the walls and bottom of the containers used for fermenting the must, storing the wine and, in particular, for treating the wines with cold.

The wine stone has the following composition:

- potassium acid tartrate KHC4H4O6 - about $65 \%$;

- calcium tartrate CaC4H4O6 - about 4\%;

- impurities from must or wine.

Tirighia is an excellent raw material for obtaining tartaric acid, because it is only necessary to replace the potassium cation with hydrogen ions, which is very easily achieved by treatment with mineral acids, most commonly sulfuric acid:

$$
\mathrm{KHC}_{4} \mathrm{H}_{4} \mathrm{O}_{6}+\mathrm{H}^{+} \longrightarrow \mathrm{H}_{2} \mathrm{C}_{4} \mathrm{H}_{4} \mathrm{O}_{6} \text {. }
$$

The collection of the wine stone can be done mechanically and chemically. After mechanical collection, the yeasts are washed with cold water, dried at low temperatures and then packed.

Dilute $2 \%$ sulfuric acid solutions are used to collect the wine stone deposited on the walls of the containers.

Vinasse presents the liquid obtained as a result of the distillation of wines raw material for wine distillates. In principle, vinasse is the same as wine, but from which the volatile compounds were separated. Vinasses are acidic effluents with high organic content, including acids, carbohydrates, phenols and unsaturated compounds [21]. The chemical composition of vinasse is shown in Table 8.

Table 8

Chemical composition of vinasse [22]

\begin{tabular}{clc}
\hline $\mathrm{N} / \mathrm{r}$ & \multicolumn{1}{c}{ Indices } & Content \\
\hline 1 & Mass fraction of suspensions, $\mathrm{g} / \mathrm{cm} 3$ & 0,049 \\
2 & $\mathrm{pH}$ & 3,20 \\
3 & Volatile acidity, $\mathrm{g} / \mathrm{dm} 3$ & 4,40 \\
4 & Total extract (without suspensions), g / dm3 & 11,40 \\
5 & Phenolic substances (total content), $\mathrm{mg} / \mathrm{dm} 3$ & 235 \\
\hline
\end{tabular}


Continuation Table 8

\begin{tabular}{llc}
\hline 6 & Total nitrogen, $\mathrm{mg} / \mathrm{dm} 3$ & 272,50 \\
7 & Amino nitrogen, mg / dm3 & 58,70 \\
8 & Glycerol, g / dm3 & 3,21 \\
9 & Tartaric acid, g/dm3 & 2,90 \\
\hline
\end{tabular}

The chemical composition of vinasse is close to the chemical composition of the wine from which it resulted. After purification it can be used in the manufacture of wine vinegar.

Of interest is the work of Mr. Odajiu Stefan, who proposed that vinasse be used as a nutrient medium for yeasts in the process of fermenting molasses to obtain ethyl alcohol, the process being the subject of a patent [23].

It was also established that, at the concentration of vinasse in vacuum, the concentrate obtained can contain up to $74.18 \mathrm{~g} / \mathrm{dm} 3$ total extract, and the content of phenolic substances reaching up to $1465 \mathrm{~g} / \mathrm{dm}^{3}$.

These vinous concentrates have been proposed for use in the manufacture of special Madeira strong wines and Brandy "Botna" strong drinks in order to increase the extractability of these products.

Thus, from the above it is obvious that, by capitalizing on wine waste, a series of valuable products can be obtained that can be used for different purposes [24 - 26].

\section{Conclusions}

Taking into account that currently only around 30 to $40 \%$ of wine by-products are used worldwide, mainly as feed or fertilisers, the recovery strategy needs to be rethought so that, properly managed, secondary wine products are reused and exploited to obtain valueadded products. The analysis of the physico-chemical composition of different categories of wine waste shows that they have a wide range of extractable compounds, which are of interest to the food industry, pharmaceuticals, etc. The use of by-products derived from the wine industry would allow to reduce to a minimum the amount of residues and to obtain valuable extracts of bioactive compounds, with multiple fields of application.

Acknowledgments: The authors would like to thank the Project 2SOFT/1.2/83 "Intelligent valorisation of agro-food industrial wastes (INTELWASTES)", funded by the European Union, within the program Cross border cooperation Romania - Republic of Moldova 2014-2020.

\section{References}

1. Naziri E., Nenadis N., Mantzouridou F.T., Tsimidou M.Z. Valorization of the major agrifood industrial byproducts and waste from Central Macedonia (Greece) for the recovery of compounds for food applications. Food Research International, 65, part C, 2014, p. 350-358.

2. Maicas S., Mateo J.J. Sustainability of Wine Production. Sustainability, 12, 2020, p. 559. doi:10.3390/su12020559.

3. Pasqualone A., Bianco A.M., Paradiso V.M, Summo C., Gambacorta G., Caponio F. Physico-chemical, sensory and volatile profiles of biscuits enriched with grape marc extract. Food Res Intl, 65(Part C), 2014, p. 385- 393.

4. Lavelli V., Sri Harsha P.S., Torri L., Zeppa G. Use of winemaking by-products as an ingredient for tomato puree: the effect of particle size on product quality. Food Chem., 152, 2014, p. 162-168.

5. Odajiu Ș. New elements in the technology of using cognac wine. Annals of the XVIII Congress of the RomanianAmerican Academy of Sciences and Arts "Moldova: scientific and cultural openings to the West", Vol. 2, p. 268, Chisinau 1993.

6. Duca B., Odajiu Șt., Musteață Gr. Patent no.592 C2 R.Moldova, Int.Cl6: C 12 P7 / 08; C 12 G3 / 12. Process for the production of ethyl alcohol // - published 31.07.96 BOPI Nr.7 / 96. 
7. Keller M. The science of grapevines: anatomy and physiology. Academic Press, Elsevier Inc., 2010

8. Kishkovsky Zn., Merzhanian A.A. Wine technology. M .: Light and food industry, 1984, 584 p.

9. Balbinoti T.C.V., Stafussa A.P., Haminiuk C.W.I., Maciel G.M., Sassaki G.L., Jorge L.M., Jorge R.M. Addition of grape pomace in the hydration step of parboiling increases the antioxidant properties of rice. Int. J. Food Sci. Technol., 55, 2020, p. $2370-2380$.

10. Antonic B., Jancíková S., Dordevic D., Tremlová B. Grape pomace valorization: A systematic review and metaanalysis. Foods, 9, 1627; doi:10.3390/foods9111627, 2020

11. Filimon R.V., Filimon Roxana Rotaru Liliana, Niculaua M. Anthocyanin content and composition of fresh and dry pomace from Vitis vinifera L. wine cultivars. Scientific Study \& Research - Biology, 25, 1, 2016, p. 12-17.

12. Yu J., Ahmedna M. Functional components of grape pomace: their composition, biological properties and potential applications. International Journal of Food Science and Technology, 48, 2013, p. 221-237.

13. Urâtu D. Development of technologies for complex processing of grape seeds. Self-report of the doctoral thesis in technique. Chisinau, 2007.

14. Filimon R.V., Niculaua M., Mihalache Arion Cristina, Anghel Roxana. Assessment of bioactive polyphenolic compounds from oenological exhausted material. Analele Ştiinţifice ale Universităţii "Alexandru Ioan Cuza" Iaşi, Secţiunea a II-a, Vol. XI, Fascicolul 2, Genetică şi Biologie Moleculară, 2010, p. 171 - 176.

15. Târdea C. Vinification treaty [Tratat de vinificație]. Ed. Ion Ionescu de la Brad, Iași, 2001, 728 p.

16. Garavaglia J., Markoski M.M., Oliveira A., Marcadenti A. Grape seed oil compounds: biological and chemical actions for health. Nutrition and Metabolic Insights: 9, 2016, p. 59 - 64.

17. Rombaut N., Savoire R., Thomasset B., Castello J., Van Hecke E., Lanoiselled J.-L. Optimization of oil yield and oil total phenolic content during grapeseed cold screw pressing. Ind Crops Prod., 63, 2015, p. 26 - 33.

18. Perez-Serradilla J.A., Luque De Castro M.D. Microwave-assisted extraction of phe-nolic compounds from wine lees and spray-drying of the extract. Food Chemistry, 124, 1652-1659, 2011.

19. Dimou C., Kopsahelis N., Papadaki A., Papanikolaou S., Kookos I.K., Mandala I., Koutinas A.A. Wine lees valorization: Biorefinery development including production ofa generic fermentation feedstock employed forpoly(3-hydroxybutyrate) synthesis. Food Res. Int., 73, 2015, p. 81 - 87.

20. Razuvaev N. I. Complex processing of secondary wine products. Moscow, Food Industry, 1975, 168 p.

21. Salgado J. M., Rodriguez N., Max B., Perez B., Rodriguez R., Cortes S., Dominguez J. M., Evaluation of wine vinasses asalternative nutrients in biotechnological processes. CyTA-Journal of Food, 9, 2011, p. 278 - 281.

22. Duca Gh. Secondary wine products. Ed. Știința, 2011, p.112-143.

23. The Law of Vine and Wine. Chisinau, 2007, 16 p.

24. Elena Cristea, Rodica Sturza, Paula Jauregi, Marius Niculaua, Aliona Ghendov-Mo[anu, Antoanela Patras. Influence of $\mathrm{pH}$ and ionic strength on the color parameters and antioxidant properties of an ethanolic red grape marc extract. Journal of Food Biochemistry, 2019. https://doi.org/10.1111/jfbc.12788.

25. Spinei A., Sturza R., Moșanu A., Zagnat M., Bordeniuc Gh. The use of anthocyanin extract obtained from wine products in the prevention of experimental dental caries. Romanian Journal of Dentistry, Vol. XX, nr. 3, 2017, p. 161-175.

26. Ghendov-Mosanu A., Sturza R., Chirița E., Patraș A. Valorization of winemaking by-products in the production of jelly candies. Italian Food Materials and Machinery, Food Research, September, 2016, p.12-15. ISSN 22396047. 